\title{
ECHOES OF THE INFERNAL MACHINE: 1940s FRENCH AND ENGLISH LITERATURE OF RESISTANCE AND COLLABORATION AS A REVOLUTION IN THE MYTHIC IMAGINATION
}

\author{
Tadd Graham Fernée
}

New Bulgarian University, Sofia, Bulgaria

\begin{abstract}
This article comparatively examines French and English literature based on two novels published in 1947, Malcolm Lowry's Under the Volcano and Jean-Louis Curtis' The Forests of Night. Both novels employ the mythic device to construct narratives on the twilight of the British Empire and the German occupied French Vichy regime, respectively, depicting experiences of resistance and collaboration on the eve of and during the Second World War. Both invent a system of symbolic imagery modelled on the Surrealist template in Jean Cocteau's The Infernal Machine, that turns the classical mythic device still prevalent in the early $20^{\text {th }}$ century (i.e. in Joyce or Eliot) upside down. The revolution in Mythic Imagination follows the Structuralist Revolution initiated by Durkheim, Saussure and Bachelard, evacuating fixed ontological architecture to portray relational interdependency without essence. These novels pursue overlapping ethical investigations, on "non-interventionism" in Lowry and "fraternity" in Curtis. The novels raise questions about the relation between colonialism and fascism and the impact of non-Western mythic universes (i.e. Hinduism) upon the Mythic Imagination. They have implications for our understanding of gender relations, as well as the value of political activism and progress.
\end{abstract}

Keywords: $2^{\text {th }}$ century modernism, English-French literary comparison, Malcolm Lowry, Jean-Louis Curtis, Jean Cocteau, French Resistance, anti-colonial struggle, Indian philosophy, Structuralism and myth, gender politics

\section{Article history:}

Received: 7 December 2019;

Reviewed: 16 December 2019;

Revised: 18 December 2019;

Accepted: 20 December 2019;

Published: 30 December 2019

\section{Copyright (C) 2019 Tadd Graham Fernée}

This open access article is published and distributed under a CC BY-NC 4.0 International License which permits non-commercial use, distribution, and reproduction in any medium, provided the original author and source are credited. Permissions beyond the scope of this license may be available at tfernee@hotmail.com. If you want to use the work commercially, you must first get the authors' permission.

Citation: Fernée, T. G. (2019). Echoes of the Infernal Machine: 1940s French and English Literature of Resistance and Collaboration as a Revolution in the Mythic Imagination. English Studies at NBU, 5(2), 220246. https://doi.org/10.33919/esnbu.19.2.3

Tadd Graham Fernée is part of the Department of Foreign Languages and Cultures of New Bulgarian University. He is a researcher for New York University, and the author of The Enlightenment and Violence: Modernity and Nation-Making (2014).

E-mail: tfernee@hotmail.com (D) https://orcid.org/0000-0003-4364-3463 


\section{Books of the Dead: Myths for remembering or burying the 1930s-40s}

Malcolm Lowry's Under the Volcano is a Book of the Dead for the British Empire. Jean-Louis Curtis' Les Forêts de la Nuit is a Book of the Dead for the French Third Republic. Both were published in 1947, the year of Indian national independence. Forests won the prestigious 1947 Prix Goncourt. Volcano inspired a generation of experimental writers. Jack Kerouac wrote to Neal Cassady in 1951 that it is "the best (for you) since Proust [and] Joyce" (Charters, p. 325). The title Forests refers to William Blake's 'The Tyger' in Songs of Experience (1794), while Volcano invokes Charles Baudelaire's 'Forest of Symbols' from the 1857 Flowers of Evil. In featuring doomed heroes in predetermined universes, however, both foremost reproduce Jean Cocteau's Infernal Machine (1932) as a modernist template. Cocteau modernized Sophocles' Oedipus the King. This commonality grounds their revolutionary shift in the $20^{\text {th }}$ century mythic imagination.

A political activist or resistor, and a paralyzed will or collaborator, are somehow a single person behind the double, just as Sophocles' Oedipus actively fought fate as prophesied, only to become its passive instrument in a pre-recorded universe. In Forest, paralysis of the will is represented in Gérard. He tortures himself over the suspicion of passive collaboration, yearning for the heroism of the Resistance. Gérard's options are based upon a cast of mythic constructs that enslave him within a system of mass production, cynically manipulated, obstructing original or authentic action:

It is a dirty time to be alive ... you want to chuck in your job. You want to throw yourself into the tricks and the black-market trafficking, like so many others. After all, you needn't be very cunning. Just an absence of moral scruples and some guts... What am I doing in this world, when all is said and done? Neither a terrorist, nor an active collaborator, neither a black-market shark nor a dissident hero ... Neither good nor bad, neither great nor even mediocre, just one more instance of mass production (Curtis, p. 101).

Knowledge cannot alter the future. This, of course, undermines the central modern Enlightenment tenet: objective knowledge can help to avoid suffering produced by foreseeable consequences. Where the future and past are equally fixed, abandonment of hope removes needless suffering from inevitable suffering. Helene de 
Balansun, in Forests, the sister in a sibling duo echoing Cocteau's Enfants Terribles (1929), thus invokes the Infernal Machine:

"Everything is a vast joke, to make us suffer slowly. Nothing ever ends. We say that hope is a theological virtue. I think sometimes it's the most sinister torture inflicted upon humankind. What a sweet rest, the day that no possibility for hope remains. This afternoon, I remained mad with joy that the Americans had arrived in Africa. Now it appears another trick in the universal joke. Later tonight, my belief will reawaken" (Curtis, pp. 119-120).

The Consul, in Volcano, finds "sanctuary" in "the paradise of his despair", like "the scorpion, [who], not wanting to be saved, had stung itself to death" (Lowry, p. 338). The disgust felt by the characters over hope springs from mistrust of information circuits: public and private. Rejection of hope correlates to spurning democracy: for, the conflicting solidarities and hopes of everyday people are the fundamental legitimation of democracy as the non-violent negotiation of differing interests and values, ironically born violently in the French revolution of 1789. It envisions the possibility of progressive change by ordinary people. In a personal account of the French Resistance, Contre L'Oubli [Against Forgetting], by Henri Lecres, it is written:

The dead remain alive for as long as the living do ... I wanted to restore this past episode to the present in order never to be forced to relive it. History is not an exact science, but an eternally new beginning (Lecres, pp.10, 149).

Lecres "new beginning" is, of course, the wellspring of hope. The future is unmade. A contemporary affirmation of the Enlightenment, it is one more voice in the information war that inspired Helene's wish for hope's extinction that she might rest. She yearns to "to remember nothing, to envision nothing ... To crush the last cold ray of consciousness", that she might live "in the night forever, and all the rest be abolished" (Curtis, pp.154-156).

Just as Helene's utterance invokes the postmodern annihilation of the "subject", or rational consciousness, both Volcano and Forests have been acknowledged as novelistic embodiments of the twilight of modernism. In a 1992 study of Lowry's writings, Sue Vice wrote: 
It preserves all the features postmodernism is credited with: it celebrates not the autonomous modernist work but the provisional, contingent text [in] the death of the subject and the author; it relies on pastiche and collage [while] using traditional forms in displaced manner [such as] Aztec deities, Mexican history, and a whole lore and language of the cantina [which displace] the usual high modernist unrest in Christian myths and European history (Grace, p. 133).

Vice argues for the distinctiveness of Volcano. It is neither "modernist" nor "postmodernist", she contends, because - unlike "William Burroughs" - it is a "collage with conscience" and a "dialogic novel" (Grace, p. 133). This could also be said of Forests. A 2007 review identified the "key" to the novel in the quintessentially postmodern deconstruction of meta-narratives, or "predominant ideas, great slogans, anthems, and boasts, in fabricated poses built on false pretences." Yet, in deeply human fashion, the novel plunges the reader into the "genuine feel of the time, far from the reconstructions forced upon collective memory" (Penvin, 2010). The recent Sebastian Faulks novel, Paris Echo (2018), uses Forests as almost a historical alter ego while - again in a postmodern pathos - examining the "possibility of seeing ourselves from a different angle" (Bari, 2018). Yet, Forests remains a somehow obscure book in France, a piece of the underground consciousness linked darkly to the Vichy memory, and therefore correspondingly little read in Anglophone circles as exemplifying French modernism. Though comparatively famous, Volcano shares with Forests a certain marginal status in modernist literature, which, despite being a "masterpiece" "revisited year after year by a few zealous defenders", "the rest of the world [remains] only barely aware of ... as an exotic and harrowing read" (Kerr, p. 21). Yet, I argue that these novels neither anticipate postmodernism, nor affirm humanism, despite commingling these unlikely currents. They commonly invoke a pathos of tragedy in which beautiful precision is built upon preordained movement. As in Friedrich Nietzsche's Eternal Return, neither the divine justice of Theodicy nor Enlightenment progress survive. Nietzsche called this the "the innocence of becoming" (Nietzsche, p. 35). Divine determinism reasserts itself through divination in the bloody evisceration of Cocteau's Infernal Machine, as an experience of exstasis produced by forgetting. Forgetting is collaboration with fate; remembering is resistance to create change. 
The core Infernal mechanism, from Sophocles to Cocteau, is forgetting. The $20^{\text {th }}$ century revolution in the mythic imagination occurs here. The rapidity of industrial transformation creates a society which differs day by day, rupturing continuity. This inflicts blindness where, every day, sight is regained, but always without adequate time to cultivate clarity. Cocteau wrote: "Our machine dismembers itself more every day and every morning man awakens with a new shackle" (Cocteau, 1989, p. 163). In Sophocles, prophets incarnate an unknowable fate whose being is, by nature, forgotten. Cocteau substitutes this with forgetting in industrial fugacity, requiring a new type of myth "never envisioned en bloc" (Cocteau, 1989, p.140). In both, a constellation of irrational actions produces amazing coincidence, but the succinct oracular utterance yields to information war which deploys myth to seize power.

Cocteau's 1925 Enfants Terribles described two housebound orphans, sister and brother, cut off from the outside, losing their identities in obsessions with the Hollywood femme fatale and American film heroes. An industrial inheritance flow sustains their isolation. Their mythic world includes slavery, doublings, sacrifices and miracles, living "as in the movies", becoming insomniac "wandering souls" haunted by "spectres", meeting violent ends in the "game" (Cocteau, 1925, pp. 48, 81-2). Gradually drawn into the outside world - the sister entering the fashion industry as a model - their "innocence" is destroyed. It is an "innocence" at once "animal and vegetable", driven by "dark instincts", retained "in memory no more than pain", an "alien world" invisible to adults (Cocteau, 1925, p. 8). This was Cocteau's first sketch of the Infernal Machine, unveiling the "forgotten" abyss dividing being from appearance:

The trap sprang open and extended its winding machines. The moribund and the young woman touched it, turned it over, dismantling the gears of the Infernal Mechanism one by one (Cocteau, 1925, p. 119).

This template corresponds to both Forests and Volcano. A family tragedy follows the inside/out workings of an Infernal Machine. Each explores a philosophical problematic. Volcano engages Tolstoy's non-interventionism (i.e. the state is institutionalized violence, opposed to the 'law of love' in Christian doctrine), against Empire's twilight and the non-interventionist policy of the Liberal Powers during the Spanish Civil War (1936-39). Forests engages French Revolutionary "Fraternity" (i.e. 
"Liberty", "Equality" and "Fraternity"), a mandate for direct popular action, under Nazi German military occupation and the collaborationist Vichy regime (1940-44).

\section{Nationalist Myths: the Revolutionary Republic and the Counter-Enlightenment}

Forests describes Saint-Clar under Nazi military occupation, a south-western village bordering the non-occupied "free zone" of the Vichy regime (1940-42). France was bisected by the 1940-42 demarcation line, suggesting doubling or split personality. Historical sources employ a Cocteau-esque language of the mirror to describe the "cruellest predicament faced by the French people in their history":

On May 10 1940, the French army, reputedly the largest and most powerful in the world, was destroyed within a month by the German Blitzkrieg ... Maréchal Petain signed the June 22 armistice, appealing to the people in the name of patriotism, for cooperation with the occupying force in the national interest ... From London, General de Gaulle, with his call of June 18, announced the continuation of the struggle outside of French borders and in the colonies ... On the other side of the mirror, Vichy France sank ever deeper into a spiral of collaborationism (Arnaud et. al., pp. 129-130).

By tracing the destinies of French resistors (seventeen-year-old Francis de Balansun), collaborators (Mme Costellot, who causes his death) and those floating in paralyzed limbo (Gérard), Forests subverts the resistance-collaborator binary to examine shockingly ambiguous and complex identities. Post-war France nurtured a nationalist myth of Resistance. Most Frenchmen had been resistors, through arms or civil disobedience, opposing a few collaborators. Unrevised by historians until the early 1970s, Forests unsettled the myth decades before:

Official opinion distinguished two camps: the good and bad, the wicked and heroic ... Yet the reality was far less simple. Between extreme attitudes, there were middle terms ... Beneath crude labels attached to people, there were many thousands of nuances possible (Curtis, p. 255).

Forests depicts a joke of the gods in an Infernal Machine. It follows Cocteau's summation of the Infernal Machine in "the gods exist" and "they are the devil" (Cocteau, 1934, p. 5): 
For an Olympian, it must have provided a puzzle of the highest comic order ... Everything could be multiplied ... through infinite combinations, spiced with death. The Olympians had to be rolling with laughter. Everything endured the upheaval of Primeval Chaos, unwanted tourism, on a scale completely derailing the European Machine, its schedules ruled by a probability as fantastic as its weather forecasts, where only Chance was king (Curtis, p. 121).

Francis - the principal hero - aids resistors in fleeing across the border. The frontier has a metaphysical meaning in the place where all worlds meet. The opening border-crossing pairs the fallen Count's child, Francis, with a resistor from the inferno of the Paris underclass, the "Mohican". His name echoes the colonies, cementing urban misery and distant conquest. Their dialogue embodies Innocence and Experience. Wars and revolutionary mass movements suppress barriers separating classes and social groups, opening unprecedented dialogic horizons and social possibilities.

The "Mohican" describes brutal poverty and violence, a life of thieving, as an orphan whose adoptive mother perished insane in a public hospital. He initially hates Francis' naiveté, mimicking him: "I don't hate anyone, I'm too well brought up for that. Hate is fine for the lower classes". The "Mohican" ultimately feels a bond of "Fraternity" (Curtis, p. 33). The Infernal Machine hovers invisibly. The "Mohican" asks Francis: "Do you think that everything will be finished when the Germans are driven out, when the country has recovered its liberty, and when the entire French population sings a song of victory, communists and Christians together?" When Francis replies, "Yes, I think so ... I hope so", the "Mohican" retorts: "In that case, you are mistaken. No, it will be only the beginning" (Curtis, p. 35). Hope is the engine of destruction. Francis assigns the "Mohican" the task of discovering the whereabouts of Helene's fiancé, a French soldier imprisoned in Sargasso. It triggers the anonymous cause-effect patterns leading to Francis' death, demolishing the Balansun family on the eve of the Liberation. The "Mohican" is the oracle, his discourse ratified by a constellation of unconscious actions.

Francis embodies the Lamb in Blake's "Innocence-Experience" duality. The Creator of the Lamb equally created the Tyger (Mme Costellot; the French Gestapo; the mafia) that kills him. God is simply a mirror, equally capable of loving kindness and lethal violence. Theodicy is subverted by ordinary causality, as, "underneath the 
disorder, hate flowed through the radios night and day" (Curtis, p. 121). Mme Costellot, having once suffered a slight by English snobs, becomes a fascist collaborator on equally random grounds:

After June 1940, her morbid condition exploded like a tropical flower... Mme Costellot cherished her sickness. She cultivated it. With the help of newspapers, it became a natural fever equal parts anti-Semitic and anti-Masonic... She devoured Anglophobe literature... She elaborated a philosophy of History... Judeo-Saxon capitalism was the cause of all their miseries... She availed herself of arguments alternately insidious and gigantic, abstract and emotional... (Curtis, pp. 164-5).

Francis is an unlikely hero, presenting his mission as flotsam and jetsam on life's sea. He tells Gérard, upon being asked how he joined the Resistance:

They didn't ask me to sign a contract, you know! The man who I assisted in crossing the border charged me with a commission to do another. This second one confided me with another project elsewhere. And so on. It was very simple. Papa makes a big mystery of the story. You know how he dramatizes everything. It really wasn't such a big deal (Curtis, p. 242).

Francis embodies "chance". The Count's "faith" underpins his "dramatizations". In pre-revolutionary mythos, a Great Chain of Being grounded a divine order behind events. Against "this materialistic era", the Count upholds the "virile disciplines of antiquity" (Curtis, p.18). He combines colonial overseer with fallen European lord:

At rest, he resembled an English engraving of the Sahib, the administrators of British India, or an officer in the Bengali regiment. In motion, he again became what he really was: a democratized Gascon gentleman, the petty nobleman whose ancestry were forced, after 1793, to abandon their castle and, subsequently, to become a scrivener, but who had retained ... something of the distinctive breeding of the old world, all the while mitigated by bourgeois geniality (Curtis, p. 17).

The Count's commitment to a "crusade in defence of the French cultural heritage" echoes counter-revolutionary French politics (Curtis, p. 20). Joseph de Maistre had argued in the $18^{\text {th }}$ century for a "return" to the hierarchic order of church and throne, while denouncing "humanity" (i.e. the Fraternity principle). Count Balansun 
hails from a noble family defined by "heroic conduct", but violently uprooted with the 1789 French Revolution. His illustrious ancestor:

[...] mounted the steps to the guillotine with arrogance, shouting at the crowd, shouting the family motto 'Always Higher' to the executioner. It brought tears of laughter to the eyes of the old women knitting below, knowing his head would soon tumble down into the basket set up below the scaffold (Curtis, p. 22).

Resisting "daily democratic mediocrity", the historic Balansun family aspired ultimately unsuccessfully - to resurrection through the modern regime of capitalism, as 10 $\%$ of the national income was transferred to capital during the first half of the $19^{\text {th }}$ century and wages stagnated (Piketty, p. 282): "Ruined by the French Revolution, the family sought to lift itself again through petty financial speculation" (Curtis, p. 22). The Count hybridizes nobility and capitalism, as he pursues "the path of modernism", becoming a "specialist in foreign affairs" (Curtis, pp. 23-26). The Count "juggled" a "diversity of mythological entities, from the White House, the Foreign Office, the Wilhelmstrasse, and, after 1918, the Kremlin". He dreams of "flourishing colonies, markets in the East ... and no separation between Church and State". The Count despises the secular 1789 Equality principle grounding "Fraternity". He "invented his own aristocratic version of Cartesian philosophy, [and] held his domestic servants as 'rabble' and simple machines" (Curtis, p. 59). Conspiracies and Theodicy provide his mythic strategy for coping with European modernization. In this way, the Count embraces fascism:

[...] the world situation was just about settled; Germany would conquer the 'Soviet-Jewish-Saxon coalition' ... The Count had spontaneously and, without discussion, embraced the [fascist] programme of the New France; and, with him, many thousands of honest and decent people across France. He was a collaborator with neither passion nor acrimony (Curtis, pp. 58-59).

The "decay of the Balansun family" corresponds to Edgar Allen Poe's 1839 House of the Fall of Usher (Curtis, p. 23). A noble family irreversibly declines, marooned in nostalgic dreams. The Count's son becomes a doomed resistor, his daughter the lover of an underclass black market gangster, then ultimately the quasi-slave of a wealthy bourgeois, Mr Costellot, in the post-Liberation order. Mme Costellot "pushes a trigger and sets the machine in rotation" which leads to Francis' death (Curtis, p. 259). He becomes a scrap of information manipulated as propaganda in the post-Liberation 
power struggle, "a dead who brings profit" (Curtis, p. 410). The transmission of noble power is terminated, as the Count's children become commodities. Lowry's Volcano, similarly, recounts the decay of a colonial family in British India, who fall from Raj to rags, paralleling the French Revolutionary impact on European nobility, and the Indian national movement upon Empire's elites. The siblings in both novels explode apart, from intimate sanctuary to disaster, hiding in mythic explanations which fail to absorb the shocks from outside. Stricken with "melancholy", Helene dreams of restoring "security" and "purity", but finds it irretrievable, as with Cocteau's Enfants Terribles (Curtis, p. 216).

\section{Myths of Empire: the fall of a Black Magician}

Volcano recounts the death of Geoffrey Firmin, a British consul in Quauhnahuac, on the Mexican Day of the Dead, 1938. He is murdered by the rising forces of fascism in Mexico, alone and having rejected all attempts to help him, in a "trick of the gods" (Lowry, p. 16). The Consul is a thorough product of Empire. Born in India, he suffered childhood family tragedy:

His mother had died when he was a child, in Kashmir, and, within the last year or so, his father, who'd married again, had simply, yet scandalously, disappeared ...

One day he had walked up into the Himalayas and vanished, leaving Geoffrey, at Srinagar, with Hugh, then a baby in arms... (Lowry, p. 19).

The following memories haunt the novel, which mostly transpires over one day. A naval officer during World War I, Firmin was court-martialled, when, aboard a submarine destroyer, captured German officers were incinerated in the boiler. Subsequently, guilt stricken, Firmin received "the British Distinguished Service Order or Cross", sowing anxieties over vita activa and the mythic prestige of Empire (Lowry, p. 32). Firmin, "no less than a hero", sought "to enter the Indian Civil Service", only to be "kicked downstairs into ever remoter consulships." He ends up in Quauhnahuac, "a position where he was least likely to prove a nuisance to Empire, in which with one part of his mind ... he so passionately believed" (Lowry, p. 31). Thus, Firmin's mind is divided. Like the 1940-42 demarcation line, its apparent dualism swarms with alcoholinduced hallucinations of "familiars", or intervals where, alone, "for a moment, he could have sworn the house had been full of people" (Lowry, pp. 69, 141). Images of broken unity and proliferation define the revolution in mythic imagination. It follows the 
Structuralist Revolution (1895-1916) initiated by Emile Durkheim and Ferdinand de Saussure (Durkheim, p. 9; Saussure, p. 42). Similarly, in epistemology, Cartesianism yielded, in the revolutionary 1934 writings of Gaston Bachelard, to a "tissue of relations" instead of "simple substance", i.e. soul (Bachelard, p. 152). All species are assemblies of genes, interacting randomly with environments, without fixed or permanent identity. Identity is defined by multiple relations of difference, a flux, evacuating fixed ontological architecture. It is relational interdependency without essence. This tendency unifies both novels. In scattering every fixed edifice of the human imagination projected as a social reality, forgetting defines the relation to fragmentary mythic constructions.

Cocteau's Infernal Machine centres Lowry's narrative, when, mid-way through the last day of the Consul's life, he stumbles across the paperback, patterning subsequent events:

The Consul ... came downstairs quietly, picked up a paper-backed book lying on the table, sat down and opened it ... It was Jean Cocteau's La Machine Infernale. 'Oui, mon enfant, mon petit enfant,' he read, 'les choses qui paraissent abominable aux humains, si tu savais, de l'endroit où j'habite, elles ont peu d'importance.' ... 'The gods exist, they are the devil,' Baudelaire informed him [translation: My child, the things which appear abominable to humans, if you knew, where we the gods live, are of little importance] (Lowry, p. 209).

Wandering in an evening carnival, the Consul reencounters the Infernal Machine as an attraction ride. It is linked recurrently to Hindu Dharma. A chapter opens with: Behind them walked the only living thing that shared their pilgrimage, the dog (Lowry, p. 125), a direct citation from the Mahabharata (Garrett, p. 441). In the final journey of the pious king Yudhishthira, at the summit of a holy mountain, his place in heaven is determined when he prefers to forsake heaven than abandon his dog. The Consul's dream, this anticipates the future pattern of events by mimicking the Mahabharata, inverting the image while resolving it to its carnal basis. In the final image, the Consul's cadaver is thrown into a ravine with a dead dog. The dog recurrently mirrors the fate of the characters. The Infernal Machine represents Dharma, yet conceived as a "child's structure", thus invoking Cocteau's Enfants Terribles: 
The Consul was gazing upward dreamily at the Ferris wheel near them, huge, but resembling an enormously magnified child's structure of girders and angle brackets, nuts and bolts, in Meccano; ... the wheel of the law, rolling (Lowry, p. 218).

The wheel of the law is a Buddhist concept of Dharma, the law as necessity in universal conditioning (dharmadhatu), entailing the Four Noble Truths (Vivenza, p. 72). Lowry ignores distinctions between Hindu and Buddhist thought, implying the arbitrary Orientalist imaginary which seizes fragments at random. The mythic shifts from a classically unified conception to disintegration, as mythic ensembles are deconstructed and re-intertwined in modern-classical permutations. The Upanishadic 'self-cosmos identity', or Brahminic unification, deteriorates as in Poe's House of Usher. Arriving in Quauhnahuac, the Consul had undertaken a book on comparative mythology before yielding to alcoholism. He writes to his ex-wife Yvonne, confessing a search for classical unity gone astray:

[...] do you see me as still working on the book, still trying to answer questions such as: Is there any ultimate reality, external, conscious and ever-present etc. etc. that can be realised by any means that may be acceptable to all creeds and religions and suitable to all climes and countries? (Lowry, p. 39)

The demise of a newly universalist classical unity - appropriate for Empire corresponds to the fall of Empire. The Consul resigns when the U.K. and Mexico sever diplomatically, following the 1938 nationalisation of Mexican oil reserves. He dreams of fleeing "from the people with ideas" (i.e. liberals, conservatives, socialists, or every intellectual reckoning with complex modern societies). The Consul aspires to "follow William Blackstone [in] leaving to dwell among the Indians" (Lowry, pp. 92, 126). His utopia is the mythic construct of human reality unmolested in its simplest and purest being, resembling Martin Heidegger's Being and Time (1927) in its most anti-modernist utopianism:

Why should anybody interfere with anybody? Why should anybody interfere with the Tlaxcalans, for example, who were perfectly happy in their own stricken in years trees, among the web-footed fowl in the first lagoon" (Lowry, p. 309).

Ultimately, the Consul suspects his utopia of romanticizing Empire's victims: "Indians might turn out to be people with ideas too" (358). His utopia is Empire's bad 
conscience, the mythic return to innocence. The Consul envisions becoming a "dark magician in his visioned cave" (Lowry, p. 202), retreating to an enclosed inside, fallen from the mythic universal heights defining his early life and career. His ideals of unsullied purity isolate him: "Let me truly suffer. Give me back my purity, the knowledge of the Mysteries, that I have betrayed and lost.-Let me be truly lonely, that I may honestly pray" (Lowry, p. 289). Chronic alcoholism, the Consul believes, provides access to a transcendent dimension: "how, unless you drink as I do, can you hope to understand the beauty of an old woman from Tarasco who plays dominoes at seven o'clock in the morning?" (Lowry, p. 50). It is a world populated by transcendental creatures: "Erekia, the one who tears asunder; and they who shriek with a long drawn cry, Illirikim; ... Glesi, the one who glistens horribly like an insect" (Lowry, p. 185). The Consul encounters God in this world: "do you see that sunflower looking in through the bedroom window? It stares into my room all day. ... Stares. Fiercely. All day. Like God!" (Lowry, p. 179). The Consul's heightened aesthetic consciousness implies an elitist selfcreated universe. Alcoholism is a "great battle", he states, for "the survival of human consciousness" (Lowry, p. 217). The Consul seeks "correspondences" between "the subnormal world and the abnormally suspicious", i.e. Baudelaire's "correspondences" (Lowry, p. 34). The Consul's friend, Jacques Laruelle, recognizes that the Consul is "insulated from the responsibility of genuine suffering" (Lowry, p. 219). Following the Enfants Terribles, the Consul forgets the world of others, and suffering born of responsibility for the social ceases in a private narcissism.

On the day of the Consul's death, Yvonne returns to Mexico from the United States hoping to rekindle their marriage. His brother Hugh arrives from Europe, having supported the Republicans in the Spanish Civil War, to report on fascist activity in Mexico for the London Globe. Embracing Marxism and Indian nationalism, Hugh yet suffers corrosive doubts about identity:

Is India my home? Disguise myself as an untouchable ... and go to prison on the Andaman Islands for seventy-seven years, until England gives India her freedom? ... you would only by doing so be embarrassing Mahatma Ghandi, secretly the only public figure in the world for whom you have respect. No, I respect Stalin too, Cardenas, and Jawaharlal Nehru-all three of whom probably could only be embarrassed by my respect (Lowry, p. 153). 
The Consul despises Hugh's political activism, citing a quasi-Tolstoian noninterventionism. This disguises his resistance to rescue by others from alcoholism. Eating live shellfish with toothpicks, the Consul drunkenly challenges Hugh's socialist ideals of Fraternity:

Now you see the sort of creatures we are, Hugh. Eating things alive. That's what we do. How can you have much respect for mankind, or any belief in the social struggle? (Lowry, p. 303)

When Hugh speaks of a "shark netted with a shoal of other fish and killed" as providing a "good symbol of the Nazi system which, even though dead, continues to go on swallowing live struggling men and women", the Consul retorts: "It would do just as well for any other system ... Including the communist system" (Lowry, pp. 303-4). All systems are equally condemnable. In modern reality, he contends, no meaningful differences of value separate political orders: "it seems to me that almost everywhere in the world these days there has long ceased to be anything fundamental to man at issue at all ..." (Lowry, p. 309). The Consul's non-intervention, pacific in appearance, conceals nihilism. He continues:

Ah, you people with ideas! ... All this ... about going to fight for Spain ... and poor little defenceless China! Can't you see there's a sort of determinism about the fate of nations? They all seem to get what they deserve in the long run. ... Read history. ... What is the point of interfering in its worthless stupid course? ... Countries, civilizations, empires, great hordes, perish for no reason at all, and their soul and meaning with them... (Lowry, p. 310)

Clearly, the Consul's fatalism in the late 1930s should sound the alarm over the twelve-year Nazi era, and the systematic state-sponsored killing that exterminated two thirds of Europe's Jewish population between 1939 and 1945. Penultimately, the Consul is murdered by petty fascists, having driven away those seeking to rescue him. An epiphany of mirrors strikes him, when he sees himself, at a younger age, in a brutal policeman preparing to assassinate him:

[...] the Consul knew where he'd seen him before: the Chief of the Gardens might have been the image of himself when, lean, bronzed, serious, beardless, and at the crossroads of his career, he had assumed the Vice Consulship in Granada (Lowry, p. 359). 
In the mechanics of Karma, the Consul's past returns to him. He recognizes his identity with all beings, "surrounded by these phantoms of himself, the policemen, ... the luminous skeletons, even the rabbit in the corner..." (Lowry, p. 362). His rejection of "interference", he understands, was in bad faith. Intentions, as the Buddha argued, are actions. The Consul secretly yearned for rescue from self-destruction: "For the first time the Consul scented the tangibility of his danger. ... how lonely he was ... He knew he'd half hoped all along Yvonne would come to rescue him ..." (Lowry, p. 360). However, it is too late. After being shot, the Consul experiences an epiphany of "Fraternity":

Where was everybody? Or had there been no one. Then a face shone of out the gloom, a mask of compassion. It was the old fiddler, stooping over him. "Companero-" he began. Then he had vanished" (Lowry, p. 371).

Paradoxically, the need for others corresponds to the Consul's recognition of their intrinsic otherness, negating the Brahminic absolute. Following the Structuralist Revolution, the negation of ontology implies universal identity based on non-identity, or "emptiness" as defined by $2^{\text {nd }}$ century Indian Buddhist philosopher Nagarjuna (Vivenza, p. 79). Reducing others to his phantasmagorical vision, the Consul has lacked respect for their separate autonomy:

When he had striven upwards, as at the beginning with Yvonne, had not the 'features' of life seemed to grow more clear, more animated, friends and enemies more identifiable, special problems, scenes, and with them the sense of his reality, more separate from himself? And ... the further down he sank, the more those features had tended to dissemble, to cloy and clutter, to become finally little better than ghastly caricatures of his dissimulating inner and outer self ... (Lowry, p. 361).

The Consul forgets the reality of those around him, seeing the dream surrogates woven of imagination. The root of his forgetting is the craving for a utopian simplicity, to escape responsibility embedded in complex modern realities. The Consul seeks this escape in myths: those of totalizing Empire, then those of prelapsarian purity. His awakening from amnesia resembles the Count's recollection, following Francis' death, when a "forgotten" image invades his mind in "a memory that suddenly exploded, naked, precise and pitiless" (Curtis, p. 396). The Count experiences a psychological breakdown. The arrogant veneer masking the Count's forgetting pushes his family to 
destruction, whether embracing fascism or shifting superficially to the Resistance inspired by his son's heroism. It is not coincidental that the Consul and the Count, by both professing to stumble irreversibly into "hell" as an existential reality, tragically affirm a heavenless religious universe as the denouement of their forgetting (Lowry, p. 314; Curtis, p. 394). They echo Hannah Arendt's explanation for why describing Nazi concentration camps sine ira would be not "objective", but condonement: "When I used the image of Hell, I did not mean this allegorically but literally" (Arendt, p. 159). The only hell, she suggests, is the one made by human beings for each other and themselves. Beyond Arendt's humanist argument, however, these narratives embody the Infernal Machine. Ordinary experience has mythic inevitability, an eternal pattern that is devoid of morality but perfect.

\section{Infernal Machines}

Both novels conform to Cocteau's description of "infinity" in Infernal Machine. An infinite chain of gods demands infinite obedience, tantamount to accepting fate:

Obey. Mystery has its mysteries. The gods have their gods. We have ours. They have theirs. This is what we call infinity (Cocteau, 1934, p.30).

In Volcano, the epiphany of otherness is ultimately overridden by the Consul's obsession with "correspondences". A recurrent white horse, with the number seven branded on its rump, unifies the narrative in a core "correspondence". Before being shot, the Consul releases the tethered white horse from a tree, which "wheeled around and plunged neighing into the forest" (Lowry, p. 373). Yvonne, who, with Hugh, is crossing the forest to find the Consul, is trampled to death, hallucinating fairground cars "whirling around her", the planets "burning and spinning", and the "Ferris wheel" in her final seconds (Lowry, p. 335). Neither the Consul nor Yvonne are aware of the "correspondence". Yet it confirms the Consul's supernatural sight, elevating ordinary tragedy to infinite design. His earlier delirious rantings about "Amrita, the nectar of immortality", in "the Rig Veda" and the "immolation of wives" are affirmed (Lowry, p. 307). The Consul, obsessed with controlling Yvonne in life, has her follow him into death in a further permutation upon the Hindu mythic universe. The mythic function, we see, manifests the obsessive desire to control women's bodies and lives. The Consul's final words, before being shot, are: "if only you'd stop interfering, stop walking in your sleep, 
stop sleeping with my wife, only the beggars and the accursed" (Lowry, p. 372). Volcano, like Forests, is partly about the crisis of masculinity attending the progressive advances in women's empowerment through early $20^{\text {th }}$ century experiences of war and revolutionary upheaval.

The Infernal Machine built into Forests echoes the central metaphor of the night in Louis Ferdinand Céline's Journey to the End of Night (1933). The novel culminates in a woman shooting a World War I veteran in the back of a taxi ("I will wake you up", she says) in a similar fear of increasingly empowered women in societies modernized through war and industrial upheaval (Céline, p. 490). In Forests, similarly, Gérard obsessively desires to control Helene, retaining her within the mythic frame of the Classical "Amazon". Helene finally joins the Resistance Bebop-Zazou subculture. Gérard initially hates her because she ceases to fulfil his secretly nurtured "Amazon" image. He then realizes that he has never known Helene except as his projection:

I'm a puritan bastard ... By ceasing to conform to the ideal of high nobility, that I mentally constructed for her, and by which I hoped to contain her, she has sunk in my view to irretrievable depravity (Curtis, p. 348).

The night is a metaphor of inevitability, where the chaotic flow of events advances irreversibly. Experience is depicted as blind. Surely, the depiction of chaos also conceals progressive changes, such as advances in women's emancipation. The recurrent labyrinthine metaphor of the night in Forests is a vast machine of Fate:

In this disorderly night, bristling with hatches and traps, one routinely lost one's way ... respective natures were brutally unveiled in their irreducible truth. Each person's choices were authentically theirs, and these choices irrevocably judged them. In the dark chaos of those years, each individual had to confront the lightning flash of their own truth, and struggle with it (Curtis, pp. 255-6).

Individuals are depicted as the unconscious outcome of habits engrained in ancestry, class and history, becoming embodied in mass produced "characters":

Nothing in the world could disassociate a psychological and verbal mechanism installed over many years, with the force of nature and instinct ... The puppet had become all powerful, the character had eclipsed the person (Curtis, p. 322). 
The Infernal Machine in Forests is a system of mirrors. There is no white horse as such. The relations between the characters under German occupation are simply mirror systems. Gérard is a masochist, he sees in Helene only his fantasy of an "Amazon", a "Femme Fatale", the mirror image of his own desire, not Helene. Tortured ceaselessly by guilt over being a "passive collaborator", he projects his salvation onto a woman he knows only as a reflected image. Gérard invokes his daily experience as "the crisis of masochism" (Curtis, p. 125). Helene sees only the reflection of her mythic hero, i.e. her fiancé - Gérard is the negation of that hero, as the collaborator, a coward. The Count, similarly, sees in his two children merely the reflection of his own fantasies about the past. The world is a mirror of his obsessive longing to retrieve the past, producing in him nefarious political convictions. Upon finally opening his eyes, the Count sees only "futility" in the world. His son has "died for nothing". He has "never known his century" (Curtis, p. 390-94). The Count, like Helene and Gérard, are not persons but systemic relations enmeshed blindly in the Infernal Machine. When Helene is enslaved by a bourgeois collaborator after the Liberation, he emphasizes the futility of all political struggle in terms similar to the Consul's tirades:

Whatever the Cause, theoretical communism, Hitler's New Order or American democracy with Fordist mass production, capitalist Jews, the Ku-Klux-Klan, official optimism, and Hollywood ... I would opt for American democracy, assuming I had the good fortune to be neither black nor unemployed (Curtis, p. 276).

The Infernal Machine suppresses the distinction between "ethical choices" and "personal choices". Strawberries and apples are neither right nor wrong, it is a matter of preference. "Ethical choices" are objectively right or wrong. One may choose to do wrong, by committing acts harmful to others. This choice can never make the action right. We know that many of our small everyday actions, for example, contribute to destroying the natural environment, and thus ourselves and future generations. These are objective "ethical choices". Forests implies that "ethical choices", i.e. "ideals", are a luxury of peace. In an emergency situation, ideals cease to exist. This depiction ignores figures like the Iraqi journalist Omar Muhammed, who created Mosul Eye at great risk to his life, upon deciding his only ethical choice was to fight ISIS rather than collaborate. In Forests, Francis is presented as a resistor with character (i.e. he refuses to reveal his comrades' identities under torture) but driven by "innocence" in Cocteau's sense. Adult 
resistors (i.e. Francis' leaders) are portrayed as shallow power seekers. Although such resistors exist, there are others who base their actions on "ethical choices". Forests, however, presents a vision of war as purifying human beings of their peacetime hypocrisy, and showing their nakedness as self-interested creatures for whom ethics are irrelevant. This follows the World War II Nazi collaborator Céline's metaphor of the night, which concludes that "we can never be wary enough of words", i.e. ethics or ideals (Céline, p. 487). Although Curtis disparaged fascism, he reproduced Céline's deep metaphor as an aesthetic. As Indian historian Romila Thapar argued, in Time as a Metaphor of History, even as "readings of time and history undergo mutations", sometimes a deeply shaping "metaphor remains" (Thapar, p. 44).

A similar vision sweeps through Volcano, where, although love is raised aloft as somehow supreme, the pursuit of "ethical choices" in political struggle is a futile endeavour. When Hugh argues, "But my God it's against such [an oppressive] state of affairs that people like the Loyalists-", the Consul cuts him off: "But with calamity at the end of it! There must be calamity because otherwise the people who did the interfering would have to come back and cope with their responsibilities for a change-“ (Lowry, p. 311). We needn't confuse the writer with his characters. Nor need we dismiss the argument that outside intervention is frequently a deeply unethical act. The underlying argument, however, that political action is in itself not worthwhile requires rebuttal. The tacit hostility to progressive political change in the Infernal Machine leaks through, for example, when the Consul turns his attack upon Yvonne:

[...] you don't pretend to love 'humanity', not a bit of it! You don't even need an illusion... to help you deny the only natural and good function you have. Though on second thoughts it might be better if women had no functions at all! (Lowry, p. 313)

Consider, as a counterpoint, a figure like Colette, who, roughly at this time, had experienced the end of World War I and the total reorganization of the entire French economic sector, including journalism. Colette pioneeringly broke into French journalism when women were strictly forbidden in the profession. In 1938, she wrote the story of an ex-dancer, Suzette O'Nil-Dranem, who had become the leader of a squad of nurseparachutists who explained how their actions were "forging a new destiny for women" by simply doing things that women had - according to longstanding myth - been unable to do 
(Colette, pp. 231-235). It is this side of human experience, the shattering of received limitations projected onto subordinated groups, that the Infernal Machine template seems uncapable of conceiving. These transcendent moments, by contrast, are conceived in French Resistor Lecres' "eternally new beginning", or the argument that the future is unwritten.

\section{Myths of Universal History: from classical objectivity to the mid-20 ${ }^{\text {th }}$ century breakdown of values}

As Books of the Dead, these two novels assist with the journey of the dead through the underworld of myth to the afterlife of collective memory. Only once purged of myth can we remember an event as objective universal history. Struggle over the meaning of "universal history", however, undermines immediate certainties. Early $20^{\text {th }}$ century modernism (James Joyce, T.S. Eliot, or Ezra Pound) retained moorings in the $17^{\text {th }}$ century "classical age". The "order" of the classical past, via "archetypal" myth, opposed the "chaos" of the present. In this bid for transcendence, modern life is only a fragmentary part within the eternal universality outside of the "times". This is not the universal history of Lowry or Curtis, where cosmic consciousness never gets outside of the "times". The genesis and extinction of human existence is contained in the "times" (Lowry, p. x-xiii).

Longstanding inside/out conventions, defining human identity, were thereby disturbed by the revolution in mythic imagination. This revolution had its partial genesis in the wide spectrum of realities encountered in anti-colonial struggle. The inside/out dichotomy fundamental to European modernity, i.e. Hegel's Eurocentric universal as movement of God, was deflated by multiple new realities of meaning. This is why King Yudhishthira's dog, narrated in the closing chapter of the Mahabharata, the Indian Pariah dog transposed to 1930s Mexico, defines the spiritual geography of Volcano about a British consul's journey to hell at Empire's twilight. Similarly, Forests opens with a crisis in provincial Saint-Clar, triggered by radio news of upheaval in the distant Algerian town of Mers-el Kabir. It closes with a woman adherent of Rabindranath Tagore's non-violence, a counterpoint to revolutionary republican and monarchic traditions in their century long battle before the 1940 Fall of France, being scapegoated and dragged into the street by the Liberation crowds to have her head 
shaved. The Vichy regime had built a mass campaign on the myth that emancipated women had caused the fall of France, and only by forcing them back into the home could France become strong again. Forests ends by depicting the entire accumulation of violence and hatred from the Occupation vented on women.

Mythic constructs in Lowry and Curtis correspond to a new understanding of myth, not as the cosmic stabilizer, i.e. Dharma, Nazim or the Great Chain of Being, but as redefined by Claude Lévi-Strauss in his 1958 "structure of myths" following Saussure and Durkheim. Myths reflect not the universal human condition, but "present contradiction" without resolution, where "the succession of events is not subordinated to any rule of logic or intrinsic continuity". The "contingent content of myths", combined with "diverse reproduction of characteristics across regions", constitutes the "fundamental antinomy" defining myths as ceaseless disintegration. Myths are the creations of organized power dynamics, where "nothing resembles mythic thought more than political ideology" (Lévi-Strauss, pp. 235-39).

\section{Cocteau, in The Difficulty of Being (1947), wrote:}

Beauty is one trick of nature used to attract beings to one another and ensure their collaboration. It employs beauty amidst a vast disorder. What man calls vice is common to all species. Its mechanism functions blindly. Nature reaches its ends at whatever cost. We poorly imagine the springs of this mechanism in the stars, since the celestial light which informs us results either from a reflection, or, as with all light, a decomposition. Man imagines that the stars serve as his chandeliers, but he witnesses them only in deterioration and death. It is certain that the rhythm of this great machine is a cruel one. Even the tenderest lovers collaborate (Cocteau, 1989, p.145).

Cocteau's dark view hides a political confession. Everyone is a collaborator with something cruel, irrespective of individual character. It is a blind, not a conscious, process, immune to judgement by any moral standard. Human experience is fundamentally defined by deterioration and death. It is already too late to change the future or the past. The only consolation is radical aesthetic experience. Cocteau practiced this philosophy living under the German Occupation. In his landmark 1950 surrealist film Orphée, cryptic angel utterances were based on coded BBC radio calls to the French Resistance. But under 
the Occupation, Cocteau was among the topflight French artists who "gave themselves a free pass because of their art", a "cocktail party collaborator" (James, pp. 130-31). In Cocteau's Infernal Machine, a pre-recorded universe predestines mathematically certain self-destruction. This is certainly a new myth. It is only a myth. Lowry and Curtis sought eternal harmony cutting through even the worst upheaval. This underlying aesthetic template is prone to collaboration, seeing eternity everywhere, even as Lowry and Cocteau radically pushed the boundaries of intellectual thought and aesthetic sensibility with their path-breaking visions of our time.

The theme of too late-ness or irreversibility permeates Volcano: "Over the town, in the dark, tempestuous night, backwards revolved the luminous wheel", a "corpse transported by express", everything moving with the "precision of the planets" (Lowry, pp. 42-45). Communication is ruptured by radio transmission, implying a technological remaking of human encounters. In the opening pages, the character Jacques Laruelle glimpses a street poster for the 1935 movie Mad Love, about hands lost in an accident, replaced by those of a murderer. Laruelle sees a contemporary reflection:

What a complicated endless tale it seemed to tell, of tyranny and sanctuary, that poster looming above him now, showing the murderer Orlac! An artist with a murderer's hands; that was the ticket, the hieroglyphic of the times. For it really was Germany itself that, in the gruesome degradation of a bad cartoon (Lowry, p. 25).

Laruelle muses that "a defeated Germany was winning the respect of the cultured world by the pictures she was making". He then witnesses "the first newsreels from the Spanish War, that have come back again", suggesting globally circulating news images in eternal return, blending fact and fiction, reality and myth (Lowry, p. 26). The cinematic unconscious is inverted into a paranoiac externality, watching the Consul as a spectator, echoing from the walls: "I'm watching you ... You can't escape me" (Lowry, p. 300). Manmade famine and opportunities for imperial expansion seem to have triggered a gigantic guilt complex.

\section{Labyrinth of the Guilt Complex: Doomed Heroes and anti-Heroes as Myths}

The Infernal Machine is the fundamental mythic device in the novels of Lowry and Curtis, which refers to the guilt complex. Both novels feature circular constructions. 
The heroes are doomed from the beginning. Forests opens with Francis, seventeen-yearold Resistance fighter, obsessed with circulating information as a political weapon. In the closing pages, tortured and murdered, Francis has himself become just a bit more information, used manipulatively by cynical political candidates - most of whom, fascists under Vichy, have now changed chameleon-like - in post-Liberation elections. Volcano opens with Jacques Laruelle remembering the death of Consul Geoffrey Firmin, the anti-hero, exactly one year hence - thus creating a loop which warns of how the story will end.

The characters in Volcano and Forests are obsessed with collaboration as an existential predicament: by living everyday life, one perpetuates a gigantic system of evil. This echoes Christopher Marlowe's 1592 Dr Faustus, where the desire to exploit a new mastery over the world conflicts with the limits of traditional values. But Faustus retained a lucid expectation of consequences: "Faustus' end be such as every Christian heart laments to think on, Yet, he was a scholar once admired for wondrous knowledge" (Marlowe, p. liii). Since the Faustian ancestor, the entire planet had been transformed by a vast revolutionary tide of technology and commerce producing countless unseen linkages. From steam engines to the perils of the atom, new systemic consequences were difficult to weigh in improved wellbeing for some and the terrible industrial toll on environment and populations. Cocteau's Infernal Machine captures this predicament in the succinct image of a silver pin piercing multiple overlapping folds in a piece of fabric:

If you pierce this mass with a single needle, then remove the needle, then smooth out the fabric to remove all traces of the folds, do you think a rural simpleton could ever believe that the countless holes which are reproduced infinitely at a great distance have all resulted from a single needle prick? The time of human experience is nothing more than folded eternity (Cocteau, 1934, p. 72).

Cocteau invokes this to explain a fundamental blindness in a departure from the natural processes of the Earth, and a reflection of automation in assembly lines and mass production. The problematic of "consequences" shadows heroes in a labyrinthine guilt complex. A resistor, Francis had always dreamed of a career in the colonies: "After the war, when everything had become again like before, then, undoubtedly, Francis would attend Colonial School. He had always dreamed of a post in Timbuctoo" (Curtis, p. 
234). Francis views the future as through a mirror reflecting back the myths he has internalized. The future will be as the past, for the French colonial mission is eternal. The heroism of his anti-occupation Resistance activities in no way contradicts his dream of occupying populations in Mali, who will similarly resist. Francis' heroic status as a Resistor is undermined by his enslavement to myths that obstruct his capacity to clearly see the world. One lost in illusion cannot make ethical judgments. Being ethical is the precondition for deserving the label of a hero.

Myths, as collective representations, present a cult of fatality. We are neither in the realm of force not persuasion, but ontological imperative. The Infernal Machine is a nostalgia for inevitability, or the entitlement of dominant groups. At the end of alternatives, looking back is the only option. The Infernal Machine is the nihilistic metaphor concealed inside John Osbourne's 1956 Look Back in Anger. Banalized "kitchen sink drama", supposedly purged of myth, it declares the only worthwhile state as being "a lost cause", "corrupt and futile". The iconic English "angry young man" Jimmy Porter declares political action useless:

I suppose people of our generation aren't able to die for good causes any longer ... There aren't any good, brave causes left. ... No, there's nothing left for it, but to let yourself be butchered by the women (Osbourne, pp. 101, 89).

Echoing fascist Vichy ideology, Leftist Porter embraces the myth that women are at the root of post-war England's social misfortune. Myths spread insidiously in lieu of the empowering consequentialist analysis fostering political action. The myth of an essential separation between colonialism and fascism, once dislodged, reveals them as two modalities of one form of violence. Consider how Hannah Arendt, in 1951, imaginatively built the theoretical scaffolding for historian Mark Mazower's 1998 empirical claim:

Fascism - like older imperialisms - saw its civilizing burden lying chiefly outside of Europe, [but] National Socialism did not: and just here, no doubt - by turning Europeans back into barbarians and slaves - lay the Nazis' greatest offence against the sensibility of the continent (Mazower, p. 73). 
Inside/out conventions of European identity, built on colonial domination, are subverted, unveiling a linkage between fascism and colonialism. The heroes of the French Resistance could become the oppressors in the Algerian War of Independence (1954-62) because white supremacist myths occluded an underlying human reality. Arendt had already exploded such myths: "Imperialism was born when the ruling class in capitalist production came up against national limitations to its economic expansion", in a "capitalist system whose inherent law is constant growth" (Arendt, p. 107). She analysed historically self-reproducing institutional "elements". The productive and technological power of capitalism, with its fundamentally expansive logic, were preconditions of the colonial laboratory that sired its totalitarian fruit at the heart of modern European societies. A sociological continuum united modern colonialism and totalitarianism as practices:

Many things that nowadays have become the speciality of totalitarian government are only too well known from the study of history ... centuries of extermination of native peoples went hand in hand with the colonization of the Americas, Australia and Africa ... Not even concentration camps are an invention of totalitarian movements. They emerge for the first time with the Boer War ... and continued to be used in South Africa as well as India for 'undesirable elements' (Arendt, p. 121).

A second example underlines the significance for "agency", or what we might call a hero. In 1946, George Orwell wrote about the "guilt complex" in Arthur Koestler's Arrival and Departure (1945): "it is a tract purporting to show that revolutionary creeds are rationalizations of neurotic impulses ... [A] psychoanalyst drags out of a [young exCommunist] the fact that his revolutionary enthusiasm is not founded on any real belief in historical necessity, but on a morbid guilt complex arising from an attempt in early childhood to blind his baby brother" (Orwell, p. 276). Orwell objects that, although "all revolutions fail", it does not follow that they are "all the same failure". They are not "to make the world perfect but to make it better" (Orwell, p. 278). 


\section{References}

Arendt, Hannah (2000). The Portable Hannah Arendt. London: Penguin.

Arnaud, Jean-Charles, Geny, Emeline, Lamy, Goutier, Tillier, Alice (2019). Atlas de L'Histoire de France. Paris : Sens.

Bachelard, Gaston (2008). Le Nouvel Esprit Scientifique. Paris: PUF.

Bari, Shahidha (2018, October 3). Paris Echo by Sebastian Faulks review - in the shadow of history. The Guardian. Retrieved from https://www.theguardian.com

Céline, Louis-Ferdinand (1999). Voyage au bout de la Nuit. Paris: Gallimard.

Charters, Anne ed. (1996). Jack Kerouac. Selected Letters: Volume 1: 1940-1956. New York: Penguin.

Cocteau, Jean (1925). Les Enfants Terribles. Paris: Bernard Grasset.

Cocteau, Jean (1934). La Machine Infernale. Paris: Bernard Grasset.

Cocteau, Jean (1989). La Difficulté d'Etre. Paris: Editions du Rocher.

Colette (2010). Journaliste. Chroniques et Reportages 1893-1955. Paris: Seuil.

Curtis, Jean-Louis (1973). Les Forets de la Nuit. Paris: Julliard.

Durkheim, Emile (2009). Les Règles de la Méthode Sociologique. Paris: Flammarion.

Garrett, John (1871). A Classical Dictionary of India Illustrative of the Mythology, Philosophy, Literature of the Hindus. Madras: Higginbotham and Co.

Grace, Sherril, ed. (1992). Swinging the Maelstrom: New Perspectives on Malcolm Lowry. Montreal: Mc Gill-Queen's Press.

James, Clive (2012). Cultural Amnesia. Notes in the Margin of my Time. New York: Picador.

Kerr, Sarah (1995, November 26). Under the Influence. The New York Times. Retrieved from https://www.nytimes.com

Lecres, Henri and Lecres, Denis (2013). Contre L'Oubli. Cherbourg-Toulon et Retour. Chronique de la Vie d'un Résistant 1939-47. Cherbourg-Octeville: Editions Isoète.

Lévi-Strauss, Claude (1974). Anthropologie Structurale. Paris: Agora.

Lowry, Malcolm (1967). Under the Volcano. Berkshire: Picador

Marlowe, Christopher (2018). Dr Faustus. Leipzig: Amazon. 
Mazower, Mark (1998). Dark Continent. Europe's Twentieth Century. London: Penguin.

Nietzsche, Friedrich (1998). Twilight of the Idols. Oxford: Oxford University Press.

Orwell, George (2000). Essays. London: Penguin.

Osborne, John (1996). Look Back in Anger. London: Faber and Faber.

Penvin (2007, December 17). Les forêts de la nuit - J-L Curtis. Exigence Littérature. Retrieved from www.elitterature.net

Piketty, Thomas (2017). Capital in the Twenty-First Century. London: Belknap. https://doi.org/10.4159/9780674982918

Saussure, Ferdinand de (2010). Cours de Linguistique Générale. Paris: Payot.

Thapar, Romila (2005). History and Beyond. New Delhi: Oxford University Press.

Vivenza, Jean-Marc (2009). Nagarjuna et la Doctrine de la Vacuité. Paris: Albin Michel. 